\title{
U.S. Unconventional Monetary Policy and Influences- -From Sub-Prime Crisis to COVID-19
}

\author{
Wenxing Zhang ${ }^{1, a^{*}}$, Yulan $\mathrm{Du}^{1, \mathrm{~b}}$ \\ ${ }^{1}$ School of Economics and Management, Nanjing University of Science and Technology, Nanjing, Jiangsu 210094, \\ China \\ ${ }^{2}$ School of Economics and Management, Nanjing University of Science and Technology, Nanjing, Jiangsu 210094, \\ China \\ a*381913059@qq.com \\ ${ }^{b}$ duyulan@163.com
}

\begin{abstract}
Under the impact of this year's coronavirus epidemic, the Fed resumed quantitative easing, and in the foreseeable future the monetary policy in the United States will return to normal. In order to deal with the recurrence of the U.S. monetary policy, it is necessary to deeply analyze the unconventional monetary policy and its influence. After the outbreak of the subprime mortgage crisis, the United States adopted unconventional monetary policy to make its economy recover, and this year the United States adopted openended quantitative easing to stimulate the economy again. However, whether the U.S. adopts or withdraws from the unconventional monetary policy, it will have a great impact on the world financial market, especially on the emerging economies.
\end{abstract}

Keywords: Unconventional Monetary Policy, COVID-19, Epidemic, Emerging economies, Capital flows

\section{INTRODUCTION}

The subprime mortgage crisis is the most widespread and far-reaching financial crisis after the Great Depression. After the subprime mortgage crisis, the traditional monetary policy implementation space is limited, the United States introduced a series of non-traditional monetary policy to stimulate the economy. However, after signs of recovery in the United States' domestic economy arose, the United States lost its economic foundation to continue its unconventional monetary policy. Therefore, to avoid overheating, the US phased out post-crisis expansionary policies after 2014. Many emerging economies have been hit. Turkey, Argentina and other countries have successively experienced currency crises. China's stock market also fell sharply in 2018, and the yuan depreciated $10 \%$ against the dollar. This year, under the influence of the epidemic, the United States resumed unconventional monetary policy, its monetary policy sink into a serious relapse.

In the context of China's deep integration into the world economic and financial system, the change of U. S. monetary policy will have an impact on China, China needs to respond positively to the impact. Therefore, a systematic and in-depth analysis of the background, characteristics and effects of unconventional monetary policy is needed.

\section{THE THEORETICAL AND TRANSMIT CHANNEL OF UNCONVENTIONAL MONETARY POLICY}

\subsection{The theoretical of unconventional monetary policy}

Unconventional monetary policy measures are different from the traditional monetary policy in theoretical models and transmission channels. According to Bernanke's 2009 distinction, unconventional monetary policy falls into two main categories [1]. One is policy communication, or forward guidance, in which the Central Bank communicates with the public about the future of monetary policy and directly influences the public's expectations of interest rate movements, thus influencing long-term interest rates and effecting on aggregate demand in the real economy. Another directly operates on the assets side of the Central Bank's balance sheet and can be divided into three functions. The first, closely linked to the central bank's traditional role as lender of last resort, aims to provide liquidity to financial institutions. The second, which provides liquidity directly to borrowers and investors in key credit markets, aims to mitigate the impact of impaired credit markets on non-bank markets as well as the real economy. The third is that the central bank directly buy long-term securities in the secondary market, directly influencing long-term interest rates.

Curdia and Woodford introduced the Central Bank's balance sheet into the standard new Keynes Model in 
2011, taking into account the relationship between policy dimensions and traditional interest rate policy. They argue that the central bank's quantitative asset purchase policy worked well during the financial crisis, not as a perfect substitute for traditional interest rate policies, but as a way to boost social welfare when interest rates were at zero [2]. Gertler and Karadi 2011 build a DSGE model to evaluate the effect of quantitative easing on the basis of financial accelerator model and Central Bank balance sheet constraint. The study found that QE boosted social welfare even when interest rates were near zero, suggesting that the expansion of central bank credit offset the decline in private credit.[3]

\subsection{Transmit channel of unconventional monetary policy}

The transmit channels of unconventional monetary policy are related to specific measures [4].

\subsubsection{Forward guidance policy}

Forward guidance is to influence the macroeconomic goals by guiding the public's expectations of short-term interest rates first and then to long-term interest rates, thereby achieving the transmit of monetary policy. Specifically, the central bank can frequently implement lower shortterm interest rates to generate public expectations that lower short-term interest rates will also be implemented in the future, resulting in a decline in long-term interest rates; The uncertainty of the public's expectations of the future affects long-term interest rate expectations, which in turn affects aggregate demand.

\subsubsection{Quantitative easing monetary policy}

The quantitative easing monetary policy is mainly for the central bank to purchase a large amount of financial assets in the financial market. On the one hand, it can maintain the stability of the financial market by changing the size and structure of the central bank 's balance sheet; on the other hand, by purchasing bonds Assets, increase the price of bond assets, thereby reducing the term premium or long-term yield, and thus promoting the rise in demand. Specifically, the central bank provides a large amount of liquidity to the market through credit channels and enhances the availability of credit; it transmits a long-term low interest rate signal to the market through interest rate channels and stimulates demand.

\subsubsection{Negative interest rate policy}

Negative interest rate policy, that is, by implementing a negative benchmark interest rate, the central bank can help the central bank repair the transmit mechanism of short- term interest rates to long-term interest rates and further reduce long-term interest rates. Specifically, the central bank implements a negative interest rate policy to impose "penalties" on excess reserves of commercial banks, and encourages commercial banks to use credit channels to place excess reserves originally deposited in banks into the market, increasing market liquidity and credit availability ; Depreciate the local currency through exchange rate channels, increase foreign trade exports, and promote employment and economic development.

\section{UNCONVENTIONAL MONETARY POLICY IMPLEMENTED BY THE UNITED STATES}

After the sub-prime crisis broke out, the United States immediately adopted the traditional monetary policy such as interest rate cut, open market operation and direct rescued to the system important financial institutions. The United States cut interest rates to $0 \% \sim 0.25 \%$, during 2008 and released $\$ 860$ billion a month through open market operations. The Fed injected capital directly into Bear Stearns and took over Fannie Mae and Freddie Mac. However, this series of traditional monetary policy did not effectively reverse the economic decline, the United States began to adopt unconventional monetary policy. The unconventional monetary policy of the Federal Reserve after the crisis is divided into two stages, the first stage is the three rounds of quantitative easing after the subprime crisis, and the second stage is the "unlimited" quantitative easing after the new crown epidemic.

\subsection{Three rounds of quantitative easing after the subprime crisis}

From January 2008, the Fed began three rounds of quantitative easing policy with a total value of more than 3 trillion dollars, and it continued until the end of October 2014.

Of these, the first round of quantitative easing began in November 2008 and ended in March 2010, with the Fed buying $\$ 175$ billion in agency bonds, $\$ 1.25$ trillion in MBS, and $\$ 300$ billion in long term treasuries, a total of $\$ 1,725$ billion of assets were put on the market. The Fed bought only $\$ 600$ billions of long term Treasury securities in the second round of quantitative easing, which began in November 2010 and ended in June 2011.

The third round of quantitative easing began in September 2012 by injecting funds into the market through the purchase of $\$ 40$ billions of MBS a month and expanded asset purchases in December 2012, add $\$ 45$ billion a month in long-term treasury bonds to existing MBS purchases. The Fed pulled out of the current round of quantitative easing in October of 2014, when employment and inflation hit policy targets. In all, the Fed bought nearly $\$ 170$ million in assets during this round of 
quantitative easing, expanding the Fed's balance sheet to $\$ 4.5$ trillion

The restrictions imposed in response to the outbreak have left the US economy in a near-total shutdown, which is a direct reason for the Fed to change the direction of its monetary policy.

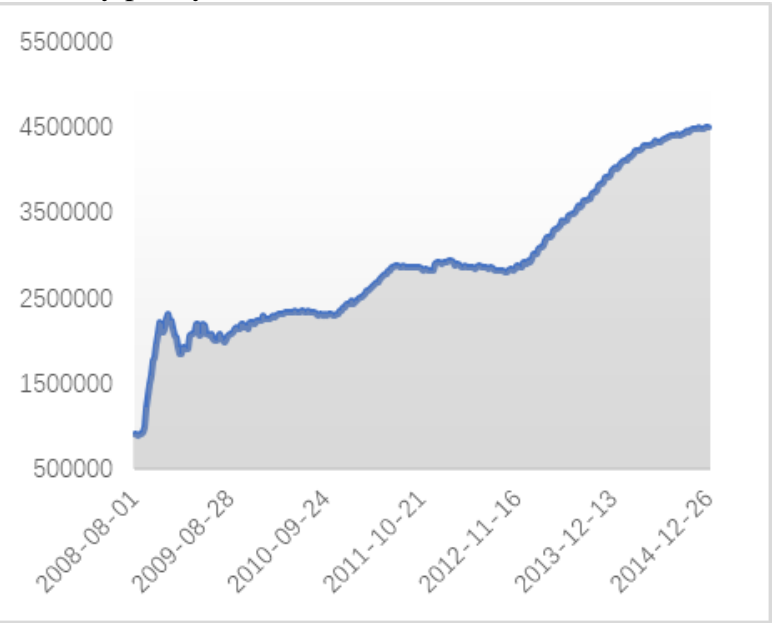

Figure 1 Fed's asset scale (2008.08-2014.12, Unit: Billon dollar)

\section{2. "Unlimited" quantitative easing after the coronavirus epidemic}

The Fed cut the federal funds rate by 100 basis points to 0 0.25 per cent on March 15 and announced a \$700bn program of quantitative easing. In addition, the open market has expanded overnight and regular repurchase operations. On March 23, the Federal Reserve issued a statement saying that it will purchase "necessary scale" government bonds and institutional mortgage-backed securities and will include institutional commercial mortgage-backed securities into the purchase category. The Fed has not set a cap on the size of its asset purchases, which amounts to "unlimited" quantitative easing, and in practice this round of quantitative easing is already well above the \$700bn originally announced. As of May 8, the Fed had expanded "unlimited" quantitative easing to nearly $\$ 3$ trillion in a very short period of time, and its balance sheet reached an all-time high of $\$ 6.9$ trillion.

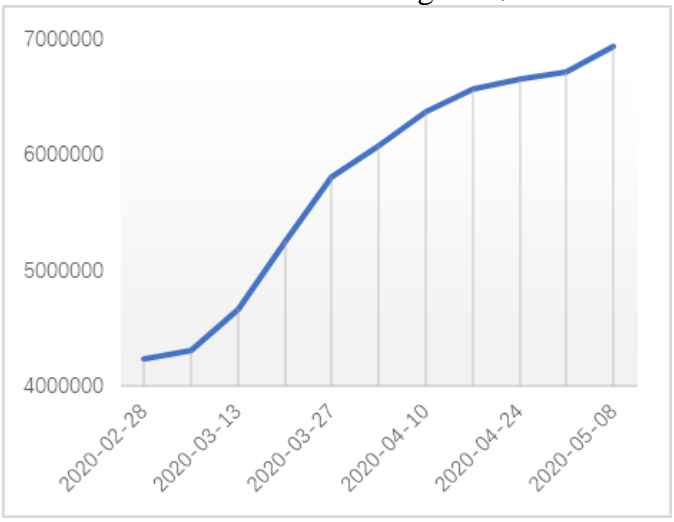

Figure 2 Fed's asset scale (2020.02-2020.05, Unit: Billon dollar)

\section{THE IMPACT OF UNCONVENTIONAL MONETARY POLICY}

\subsection{Unconventional monetary policy has contributed significantly to the recovery}

The United States economy was the first to recover thanks to the post-crisis unconventional monetary policy stimulus and began to rebound strongly in the second quarter of 2014, not only as the economy continued to strengthen but also as the workforce approached full employment, inflation is approaching the $2 \%$ target.

\subsection{Injecting excess liquidity into emerging markets and triggering a sharp rise in asset prices in emerging markets.}

The unconventional monetary policy of the United States has not only led to upward pressure on the currencies of emerging economies, but also led to a continued widening of interest rate differentials [5].

Under the influence of these two factors, the liquidity created by the United States through the implementation of unconventional monetary policy flows into emerging economies with relatively high interest rates and relatively fast economic growth. Cross-border inflows of funds have increased the money supply in other countries and led to credit prosperity, while also increasing the asset prices of capital inflow countries, and the increase in asset prices has further promoted capital flows. Therefore, the unconventional monetary policy of the United States not only promotes the currency appreciation of the emerging economies, but also leads to the increase of the leverage ratio of the emerging economies and the emergence of the asset bubble, which greatly increases the risk of economic operation[6].

\subsection{Significantly increased financial market risk in emerging economies}

Changes in US monetary policy are the key factors driving large-scale capital flows in emerging economies. As the United States gradually withdraws from the loose monetary policy environment, emerging markets will be significantly affected, especially in emerging economies with high external debt ratios, high deficit ratios, and short-term international capital inflows. Once advanced economies withdraw from unconventional monetary policies after the crisis, they will lead to a tightening of benchmark interest rates and liquidity. The U.S. restrictive monetary policy will trigger a large outflow of 
international capital from emerging economies, which in turn will lead to a decline in domestic asset prices in emerging economies. A large outflow of capital will result in a large amount of sales of currencies of emerging economies and the purchase of major currencies in the foreign exchange market, resulting in currency devaluation of emerging economies and increased exchange rate fluctuations. Falling asset prices and currency devaluation will further exacerbate the outflow of international capital from emerging economies, forming a vicious circle and even a currency crisis. In addition, the devaluation of local currencies will further increase the debt burden of emerging market economies, bringing greater shocks to some emerging economies with larger external debt and higher economic vulnerability [7].

\section{CONCLUSION}

With the deepening of globalization, countries are becoming more and more integrated into the world economic system. The change of macroeconomic policy in U.S. will have a strong spillover effect, affecting the development of emerging economies. After the outbreak of subprime mortgage crisis in 2008, the United States adopted the traditional monetary policy tools such as interest rate cut, but the existence of Zero Lower Bound restricted the effect of the traditional monetary policy, so the Fed began to resort to unconventional monetary policy. The United States gradually withdrew its ultra-loose unconventional monetary policy after signs of economic recovery arose, but it resumed quantitative easing under the impact of this year's epidemic. The U.S. monetary policy has experienced serious recurrence, which has repeatedly formed impact on the economic and financial markets of emerging economies such as China.

Unconventional monetary policy can play a certain role in the U.S. economic recovery, whether in the years after the outbreak of the sub-prime crisis or during the coronavirus epidemic, more obvious effects can be observed. However, whether the US adopts or withdraws from the unconventional monetary policy, it will have a great impact on the world financial market, especially on the emerging economies. When the United States implements unconventional monetary policies in order to promote its own economic recovery, it will trigger currency appreciation, large capital inflows, increased leverage and asset bubbles in emerging economies. When the United States withdraws from unconventional monetary policy in order to avoid overheating of the economy, it will cause currency devaluation in emerging economies and large capital outflows, which will not only increase debt pressure but also cause asset prices to plummet, and even trigger a currency crisis.
I would like to express my sincere gratitude to Professor Du. And thanks to my friends who helped me during the writing of this article.

\section{REFERENCES}

[1] Bernanke, B. (2009) The crisis and the policy response.

https://www.federalreserve.gov/newsevents/speech/ber nanke20090113a.htm

[2] Curdia, V. Woodford, M. (2011) The central bank balance sheet as an instrument of monetary policy. Journal of Monetary Economics, 58(1): 54-79.

[3] Gertler, M. Karadi, P. (2011) A model of unconventional monetary policy. Journal of Monetary Economics, 58(1): 17-34.

[4] Ba Shusong. Zeng Zhi. Wang Changyao. (2018) Theory, Effect and Implications of Unconventional Monetary Policies. International Economic Review, 2018(2): 54-79.

[5] Zhou Jianshan. (2013) International Short-term Capital Flows and their Impact on China's Monetary Policy. On Economic Problem, 2013(4): 51-54.

[6] Yu Shengguo. Guo Wenxuan. Hu Jingwei. The Impact of U. S. Quantitative Easing Policy on China's Macroeconomy: Based on TVP-VAR Model. (2018) On Economic Problem, 2018(7): 85-91.

[7] Xiao Weiguo. Lan Xiaomei. (2017) The Spillover Effect of Federal Reserve Monetary Policy Normalization on China's Economy. World Economy Studies, 2017(12): 38-49+133.

\section{ACKNOWLEDGMENT}

